\title{
Development of Tourism Village Policy in Environment-Based Empowerment Framework in Tasikmalaya District
}

\author{
Nining Latianingsih ${ }^{1}$, Iis Mariam ${ }^{1}$, Christina L Rudatin ${ }^{1}$ \\ \{nining.latianingsih@bisnis.pnj.ac.id, iis.mariam@bisnis.pnj.ac.id, \\ christina.lr@bisnis.pnj.ac.id\} \\ Business Administration Departement, State Polytechnic of Jakarta ${ }^{1}$ \\ J1. Prof. G.A.Siwabessy, Kampus Baru UI, Depok - West Java, Indonesia
}

\begin{abstract}
The tourism sector is not only is not only in urban areas, but also occurs in rural areas, because this sectoris one of the country's most important sources of forgein exchange. Negative impacts on the environment not only occur in Indonesia but occur in most parts of the world, causing problem in policy development Conventional tourism products in tourism products in tourism development in areas that are mostly Tourism Villages. The current phenomenon of tourist is leaving many tourist cities and tourist turning to tourism products that support the environment, culture, and conversation in a specially way. Tourist satisfaction is no longer based on the beauty of nature and the completeness of tourist facilities but alo the comfort and complexity of interaction with the environment and the local community. Based on the facts above, the Tourism Village Business needs to from a policy (law) as a more appropriate tourism development plan in the future so that the business will increase again. The concept of rural tourism (rural tourism) with product characteristics that are unique, distinctive and environmentally friendly should be a new solution for the development of tourism in the world. Responding to the movement of tourist, especially in Tasikmalaya Regency began to be built in several places that are in by the regions that are most in demand by regions in tourism products.
\end{abstract}

Keywords: Village tourism policy, community empowerment, village tourism management, business law, rural tourism

\section{Introduction}

The Tourism sector is one of country's most important sources of forgein exchange. Although tourism makes a significant contribution to development, at the same time it turns out that tourism industry activities also produce a number of negative impacts, such as environmental degradation, shifts in local culture and socio-economic inequality among people. As a result, there is a tendency towards market orientation and prefence shifts in selecting tourism products. Conventional tourism products are becoming increasingly abandoned and tourist are turning to tourism products that value the environment, nature, culture and attractions in a special way. Tourist satisfaction no longer rest on the natural beauty and completeness of tourist facilities but also on the flexibility and intensity of interaction with the environment and the local community. 
The formulation of the problem in this study is how the model of policy development in the tourist village of Tasikmalaya Regency is based on community empowerment. This study aims to obtain the formulation of the result of the tourism village management policy model. Tourism is an activity carried out by tourist to a tourist destination outside of daily life and the neighborhood to make a temporary stopover from the residence, which is driven by several needs without intending to earn a living and but based on the need to get pleasure, and accompanied to enjoy a variety of entertainment that can relieve fatigue and produce a travel experience and hospitably service.

The approach to tourism development is based on the ability of local people to be involved in tourism development itself. The approach that places the community as an inseparable part of the tourism product and the understanding that the tourism product is a process of social engineering of society is the essence of community-based development. The manifestation of community empowerment is through developing economic activities to support each tourism potential that grows in that environment. One such tourist destination is a tourist village in Tasikmalaya Regency.

The purpose of this study was to determine the policy model to improve the management of tourism villages in the village of Cisayong. This research was conducted using qualitative descriptive methods. This study revealed that the policy of developing and developing tourism villages in Cisayong village was directed to: a) regulate the development of tourism village activities in accordance with the characteristics of superior attractiveness and carrying capacity of the environment; b) maintain existing competitiveness; c) improve services to tourists. The policy model that will be applied is to increase tourist visits both locally and internationally in the Cisayong tourism village which consist of several variables, namely: regulations, policy standards and targets, resources, communication between organizations and strengthening activities, characteristics of related organizations and implementation activities, disposition or attitude, social, economic, and political environment and supervision must be ensured to run well. A number of problems in implementing tourism management policies in the village Cisayong includes limited human resources, and low coordination and smiliar perceptions among local government organizations (OPD), although coordination aspects are important in the efforts to encourage increased tourist visits.

\section{Research Methods}

The approach taken in this study uses a rationalistic approach. Data collections was carried out through primary and secondary surveys, sociological normative and empirical normative by collecting data not only from the literature but also in the field and field research, considering the problem under study was the policy relationship between sociological, psychological and juridical factors including customary law, review media and literature studies. In taking the sample using the purposive sampling method to get respondents competent or influential in achieving the targets obtained by using stakeholder analysis.

Analysis techniques that will be used to achieve goals and objectives include using descriptive qualitative analysis methods, with interview and observation data collection technique in the Cisayong Tourism Village. The object of this research is the policy issued by the Regional Government of Tasikmalaya Regency, West Java related to the tourism village policy. This research is a descriptive analysis. 


\section{Results and Discussions}

Discussion of the results of this study is presented in the form of descriptive descriptions, considering the collection of data obtained through interviews and documents from the local government.

There are various tourist attractions managed by the tourist village, Tasikmalaya district, including:

1. Memory of Galunggung (MOG) is to introduce and promote tourist destinations in the Tasikmalaya district, this activity is a series of anniversary of the Tasikmalaya regency that is launched every year and starts in 2019.

2. Curug sawer, location in blooming mandala, sane teak, the presence of a waterfall that forms like an enchanting curtain of water.

3. Curug dengdeng, location in pancatengan, this river presents charm and scenery among shady trees with multilevel waterfalls such as Niagara mini.

4. Panetean waterfall, the location in Pancatengah is unique, which is called curug but only has a certain height. This waterfall is called leuwi because the water flow is clear and pleasant.

5. Curug Agung Galunggung, a voluntary location, this waterfall offers an artificial rainbow at its waterfall, such as a light installation, because it can be witnessed at night also this destination is close to Galunggung mountain.

6. Curug Pamutuh, location of cigadog lewisari. This waterfall is getting the title as a hidden surge, natural shades are very beautiful. Just below the waterfall, the water flows fresh and clear, with a fairly heavy water discharge.

7. Cirahong Bridge, the location is located in the village of Manonjaya, this bridge is not a mainstream tourist destination, but has its own uniqueness with the surrounding scenery, the existence of this bridge which was built since 1893 with a bridge length of 200 meters, until now it is still a connecting railroad, motor vehicles and cars, because of the robustness of the bridge. On top of it is a train and underneath are motor vehicles and cars.

8. The santoaan root bridge, located in the village of Tenjonagara Cigalontang, this bridge is similar in Baduy and in the western part of the city, made of unique roots, this bridge crosses over a small rocky river.

9. Goa Ciguha, the location of the village of Mandalahurif jatiwaras, this cave from the bow of the earth which is still untouched because the condition of the stalactites and stalagmites is still very natural. The condition of the cave was runny in some parts, slippery and claimed by the cave community, had Long Lorong and penetrated the village next to it.

10. Goa Ciguha, the location of the village of Mandalahurif jatiwaras, this cave from the bow of the earth which is still untouched because the condition of the stalactites and stalagmites is still very natural. The condition of the cave was runny in some parts, slippery and claimed by the cave community, had Long Lorong and penetrated the village next to it.

11. Cikunten Ceuri Dam. The location is located in the village of Sukaharja Sariwangi. This dam has become important for the surrounding community as a supplier of irrigation water. Very beautiful view.

12. Oval canyon. Location in the village of Nagatu Cipatujah. This tourist destination gives off an unusual natural charm, because around this village there are rock cliffs that block the flow of the river with unique contours and beautiful scenery

13. Resik reef tourism park. Location in cipedes security. This destination is a tourist destination suitable for all age levels. The number of rides to play for children as a reason to be interesting. This place is a place for family fun 
14. Kampung Naga. This location is in Salawu Neglasari village. This tourist destination is based on local wisdom, because here we can learn the lives of citizens with a noble culture. This village still looks authentic and is still present including in talking about lifestyle. Aside from the natural nature and its cool panorama, anyone will feel at home here.

15. Karang Tawulan Beach, the location is in Cimanuk village, Kalapagenep Cikalong. This destination talks about the coastline which gives stunning views, the most amazing moment is the afternoon before sunset in the enchanting western horizon

16. Kirisik Sand Tour, Location in the village of Guranteng Pagerageung. This touris spot was built on seven hectares of land, utilizing the hills to the refreshing swimming pool.

17. Karaha Bodas, the location is in the duchy village. These attractions are charming sulfur craters and pine forests, mini-style potential has been maximized as a geothermal power plant, and still needs to be developed. For a white crater with a special view complete with hills and a combination of green, white and yellow from sulfur that brings out its own color

18. The great potential to become a leading tourism village is the village of Cisaong as a homestay tourism village, because in this village there is a Lodaya supernatural soccer field which has an international standard as a result of the community self-help. The field is 93 meters by 53 meters and can water the field automatically and can boost tourism with a monthly turnover of up to 30 million.

Out of the 18 tourism potentials in the Tasikmalaya district, there is Cisayong village, which can be realized as one of the tourist villages, because village II can generate tourist visits and serve as an example that from a simple field capable of generating visits and economic transactions, so that the village of Cisayong this will become a class from a developed village to a developed village, and it is not impossible that someday there will be the highest category in the village, that is to become an independent village

The form of tourism village management is owned by a well-managed community, taking into account several important aspects of management such as; (1) aspects of human resources, (2) financial aspects, (3) material aspects, (4) management aspects and (4) market aspects. In one organization of community organizations in the form of partnerships, corporate management, foundations or village tourism management bodies whose management elements are recruited from the abilities of the local community and prioritize the role of young people who have the educational background or skills needed (Sastrayuda, 2010).

Regarding the characteristics of Cisayong Village, a village located on the northern slope of Galungung Mountain, Tasikmalaya Regency, West Java, because of its location on the slope of the mountain, tourists who visit can enjoy the view of Mount Galunggung. In 2012, the Cisayong Village was established by the Tasikmalaya District Government as a tourist village. The characteristics of the tourism village are divided into two aspects, namely the social and physical aspects, for the social aspect consists of the daily activities of the cisayong village community including the potential of the traditional system which still applies, while the physical aspect consists of the facilities and infrastructure in the cisayong village.

Cisayong village, located in Tasikmalaya Regency, has great potential to become a leading tourism village and will be projected to become a homestay tourism village because tourists find it difficult to stay overnight. One of the strengths of the Cisayong village is that it has an international Sakti Lodaya soccer field as a result of community self-help. This field has area 93 meters by 53 meters and can water the field automatically, so as to increase tourism with a monthly turnover of Rp. 30 million. One would not have thought that behind a soccer field could make the village of Cisayong move up from the village level with the katebori progressing, because there were often ball games between districts. even dating from areas 
around the Tasikmalaya district. This soccer field is interesting, because of its international size and includes village development priorities.

Provisions of Law No. 6 of 2014 concerning Villages gave birth to new enthusiasm for rural communities in developing the economy. In the provision of Article 87 paragraph (1), a village can establish a village-owned company called a BUMDesa. Establishment and development of BUMDesa based on village community initiatives and initiatives. However, in terms of development, many BUMDESA have experienced problems, because they have developed businesses similar to those already in the village.

Supervision carried out by the Inspectorate of West Java Province found that the process of establishing BUMDesa was more than just running, operating, and developing BUMDesa. Related to this, if you want to develop the potential of the village. But Bumdes in Cisayong village has not gone well. So it is necessary to analyze the potential of villages and villages for human resource readiness. In line with this, Cisayong Desa as one of the tourist villages in Tasikmalya Regency should make strategic and planned efforts to develop the existing potential. This is an effort to support the economic development of the local village community. BUMDesa Establishment Planning is expected to be able to develop the community economy through the type of business that will be established in accordance with the articles of association and the household budget. So as to develop the economy of the new tourist village community pioneered its establishment.

The character of the social aspects of the village of Cisayong is adjusted to the condition of the area where most of the land use is used for agriculture. Due to natural conditions, the people of Cisayong village are farming more as their livelihoods. Exiting conditions in the village of Ciayong can be used as a potential attraction for tourist villages that can be utilized. Each potential was asked to respondents who had long lived to find out what the potential influences and could be developed into a tourist village, among others, agriculture, plantation, homestay, nature tourism with the waterfall that took about an hour.

The development of the tourism village in Tasikmalaya Regency is very rapid, so the Tasikmalaya regency government plans to implement a policy on tourism villages in the form of a Regent Regulation, so that the implementation and management of the wiata village has a legal umbrella. However, up to now there has not been any new planning. While the policies of each tourism village, the legal umbrella varies, starting from the sub-district permit to being managed by a tourism awareness forum.

Along with the development of the Tourism Village in Tasikmalaya district, there are several problems faced, as in table 1 below:

Table 1. Problems and solutions in the tourist village of Tasikmalaya district

\begin{tabular}{|c|c|c|}
\hline Factor & \multirow{2}{*}{$\begin{array}{l}\text { Problems faced by the } \\
\text { community }\end{array}$} & \multirow[t]{2}{*}{ The Solution } \\
\hline 1. Internal & & \\
\hline Tourism HR & $\begin{array}{l}\text { 1. Not Yet a tourism } \\
\text { communitu, so there needs } \\
\text { to be a change in the } \\
\text { mindset of the community. } \\
\text { 2. People are still less aware of } \\
\text { tourism. } \\
\text { 3. Limited opportunities for } \\
\text { tourism traning. }\end{array}$ & $\begin{array}{l}\text { 1. Socialization of tourism to the } \\
\text { community. } \\
\text { 2. Build awareness of communitu } \\
\text { tourism by providing } \\
\text { continuous traning } \\
\text { 3. Sought for funding sources for } \\
\text { training needs. }\end{array}$ \\
\hline
\end{tabular}




\begin{tabular}{|c|c|c|}
\hline $\begin{array}{l}\text { Village } \\
\text { Institution }\end{array}$ & $\begin{array}{l}\text { 1. There is no regency } \\
\text { regulation yet so it needs } \\
\text { to be made immediately } \\
\text { 2. Limited acces and } \\
\text { networking }\end{array}$ & $\begin{array}{l}\text { 3. Applied to an established } \\
\text { tourist village. } \\
\text { 4. Given access and networking } \\
\text { especially eith online media. }\end{array}$ \\
\hline \multicolumn{3}{|l|}{ 2. External } \\
\hline Tourism Support & $\begin{array}{l}\text { 1. There is no specific guide } \\
\text { for the tourism village. } \\
\text { 2. Availability of attractions } \\
\text { related to art is presented. }\end{array}$ & $\begin{array}{l}\text { 1. Trained guides from young } \\
\text { people in a tourist village. } \\
\text { 2. Present attractions are } \\
\text { provided so that guest can be } \\
\text { displayed in front of tourists }\end{array}$ \\
\hline Travel Promotion & $\begin{array}{l}\text { 1. There is tourism marketing/ } \\
\text { promotion, but it is not } \\
\text { comprehensive. } \\
\text { 2. Media Promotion is not } \\
\text { fixed. }\end{array}$ & $\begin{array}{l}\text { 3. Promoted the media for each } \\
\text { tourist village, if possible } \\
\text { through the distric web. } \\
\text { 4. Defined and assisted by the } \\
\text { regency of the city with } \\
\text { training provide for media } \\
\text { promotion. }\end{array}$ \\
\hline
\end{tabular}

Source : data Processed , 2019

Table 1 above is the result of identification of the problem, where the community is having obstacles to seek the development of a tourist village in the Tasikmalaya district. In terms of the principle of organizing a tourist village that includes economic development, social culture, environmental sustainability, maintaining the uniqueness, authenticity, local wisdom and specific nature. There is a technical requirement relating to the tourism village in the City of Tasikmalaya, which is community-based Community tourism (CBT) that continues to empower the community and in that community there is attraction as one of the flagship, and there is a place that is centered on community activity

The process of establishing a tourism village in Tasikmalaya Regency still requires SOPs such as that citizens can submit applications to become known tourist villages RT, RW and community leaders, to the Regent after going through the Lurah, then arranging the tourism village administrators, making a tourism profession and having a program it works.

The implementation of rural tourism in the Tasikmalaya district is categorized into several tourism programs, namely Nature Tourism, Ciakar Agro Tourism, Sites, Pilgrimage and Religious Tourism, Craft Tourism, Culinary Tourism, Shopping Tourism, Artificial Tourism and Special Interest, all of which must be under the supervision of the village tourism manager. The Village tourism program in Tasikmalaya Regency is needed by the management / manager which consists of the Chairperson, secretary, Treasurer, and other sections in charge of the required affairs.

The The duties and functions of the board are as follows:

\section{Task:}

1. Managing the potential and attractiveness of tourism that is characterized by unique, authentic, specific, and local wisdom so that it becomes an attractive and worthy tour package.

2. Prepare attractions in accordance with the routine of community life carried out daily.

3. Preparing the community as a tourist business.

4. Preparing the facilities and infrastructure that have been determined. 


\section{Fuction:}

1. Planning, implementing and reporting village tourism program activities.

2. Report the results of the implementation of programs and activities to the local government.

3. Institutions can form legal entities such as cooperatives

its development there is a classification of tourist villages, namely Pioneer, Developing and Independent. The classification of wista villages is based on the results of the assessment conducted by the assessment team formed by the Regent's own statement. The elements of the assessment team consisted of practitioners in the field of Tourism, academics, elements of service, elements of other regional apparatuses according to needs and other elements according to needs. The tasks of the assessment team are:

Evaluate the determination of tourism villages as a basis for consideration of determining the classification of the assessors once every three years or according to the situation.

a. Conduct field visits, gatherings, studies in order to assess, supervise and evaluate, and foster village tourism

b. Prepare recommendations for solving problems and developing the potential of tourism villages on a regular basis once a year

c. Assist in the implementation of rural tourism programs and activities carried out by the regional apparatus

While the functions of the Appraisal team are:

a. Provide consideration and direction in the management of tourism villages:

b. Assess each proposed formation of a tourism village;

c. Monitoring and evaluating the management of tourism villages; and

d. Assist in the implementation of rural tourism programs and activities carried out by the regional apparatus

The determination of the evaluation of the tourism village assessment will be carried out periodically, for example 3 years from the date of stipulation. So that in three years' time can be improved and structured even more enhanced, and possible to rise to a higher level. The Regional Government's main task in tourism activities is in terms of providing promotional support and information directed to promote tourism potential and inform the public at large. Forms of promotion and information support can be done by: Making information material; Database creation and updating; Potential exhibitions and performances; Documentation of activities; Development of collaboration with stakeholders; Utilization of information technology. In addition, the Regional Government provides facilities and infrastructure that are directed to have adequate facilities and infrastructure for the development of Tourism villages. The form is in the form of: (a) Development of public facilities; (b) Provision of accessibility and (c) environmental infrastructure; and (d) Tourism village markers.

For Coaching in the form of facilitation of organizing events and competitions conducted to promote and measure the level of development of Tourism villages. Such as (1) The facilitation of organizing events and competitions is carried out in the form of exhibitions and potential events held by Tourism villages. (2) Organizing events and competitions in the form of: (a) Degree of tourism potential, (b) Event of the Tourism village event; (c) Tourism village competition; (d) Competitions of types of tourism potential. 
As for what is generally regulated in the Regents Regulations, the following rules are:

1. The principle of organizing a tourist village

2. The formation of a tourist village

3. Institutional

4. Classfication of a tourist village

5. Tourism village communication forum

6. Coaching

\section{Conclusion}

1. Toursit village in Tasikmalaya Regency is a tourism village with great potential, such as natural potential and human resource potential (community), so it needs to be developed.

2. Until now there has been no policy to manage the tourism village as a whole.

3. This Tourism Village has had a positive economic impact on the village community. Increasing community income and employment for rural communities.

4. Another positive impact of this tourism village is the social impact seen from community cohesiveness such as mutual cooperation in terms of maintaining cleanliness, security, building public facilities and so on.

5. The Tourism Village also preserves its culture as a characteristic of this village such as the Reog group, theatrical plays, traditional dances, musical performances and the Earth Alms ritual.

\section{Acknowledgments.}

The author would like to thank the State Polytechnic of Jakarta, Kemenristek Dikti for the funding and permission to use its facilities for research.

\section{References}

[1] Somov, A.: Wildfire safety with wireless sensor networks. EAI Endorsed Transactions on Ambient Systems. pp. 1-11 (2011)

[2] Motaz, A.: Start programming using Object Pascal. Vol. 2, pp. 10-11. Legally Free Computer Books, US (2013)

[3] Ahimsa, Putra. 2000. Ketika Orang Jawa Nyeni. Yogyakarta: Galang Press Badan Perencanaan Pembangunan Nasional 2010. Buku Potensi Ekonomi. Basuki. 1992.

[4] Croes, R. R. (2006). A paradigm shift to a new strategy for small island economies: embracing demand side economics for value enchancement and long term economic stability. Tourism Management, 27(3), 453e465.

[5] Pendit, Nyoman S. 2006. Ilmu Pariwisata: Sebuah Pengantar perdana. Jakarta: Pradnya Paramitha.

Ramli, Najmudin. 2007. Pariwisata Berwawasan Lingkungan. Jakarta 
Scheyvens, R., \& Mornsen, J. H. (2008). Tourism and poverty reduction: issues for small island states. Tourism Geographics, 10(1), 22e41.

[6] Subagyo. 1991. Modern sebagai manusia. Jakarta: Jembatan

[7]Suryana. 2003. Kewirausahaan pedoman praktis, Kiat dan proses menuju sukses. Jakarta: Salemba Empat Yoeti, Oka. 1996. Pengantar ilmu Pariwisata. Bandung: Penerbit Angkasa

[8] Latianingsih, Nining. 2010. Implementasi hukum bisnis melalui kegiatan koperasi sampah dalam rangka pemberdayaan masyarakat. Jurnal Ekonomi Bisnis PNJ.

[9] M. Jaafar, S.A. Maideen. School of Housing Building and Planning, Universiti Sains Malaysia, Minden, 11800 Georgetown, Penang, Malaysia / Tourism Management 33 (2012) 683e691 journal homepage: www.elsevier.com/locate/tourman

[10] Medlik, S., \& Middleton, V. T. C. (1973). Product formulation in tourism. In. Tourism and marketing, Vol. 13. Berne: AISET 